\title{
Chapter 18 \\ The Significance of Scientific Research in the Professional Development of Students
}

\author{
Mukhabbat Ikrami
}

\subsection{Introduction}

The development of the modern food industry has a number of peculiarities, among which the most essential are the following:

- Increases the significance of the functional and balanced articles of food (related to many food substances) and products of the therapeutic and prophylactic purposes required for the certain population groups and aimed at providing therapeutic and dietary actions. A wide range of consumers - children, elderly people, workers of the hazardous industries - need these healthy articles of food.

- An important task of the food industry is to find new sources of raw materials, to construct new articles of food and to create new food processing technologies.

- The urgent problem is to develop new techniques and to improve the existing methods of analysing raw materials and articles of food, as well the methods of calculation of their nutritional value.

Addressing the foregoing problems requires not only the training of specialistsgeneralists possessing the knowledge of the basics of modern production and the methods of technical-chemical control but also:

- Possessing the knowledge of narrow-profile specialists, having had in-depth fundamental and professional training

- Being able to conduct scientific researches, as well as complex scientific experiments and observations

M. Ikrami ( $\square)$

Chemistry Department, Tajik Technological University, Dushanbe, Tajikistan

e-mail: ikromi_14121950@mail.ru

J. Drummer et al. (eds.), Vocational Teacher Education in Central Asia,

Technical and Vocational Education and Training: Issues, Concerns

and Prospects 28, https://doi.org/10.1007/978-3-319-73093-6_18 
- Being able to use new data about the known elements and chemical substances that are not synthesized in the human body but are vitally important, as the only way they can pass into the human body are through articles of food

- Being aware of the chemical and physical processes occurring in the food production in order to manage and to optimize the processes.

The urgency and importance of this work consist in the fact that the scientific activities of students are an integral part of the learning process. Besides, it has the great importance in improving the quality of instruction, developing the creative potential of students and improving the formation of professional skills as well as self-reliance and the ability to think and to make decisions.

A large number of academic papers describe the research activities of students, their place in the educational process and their significance. For example, "the scientific activities of students will play a leading role in improving the quality of specialists' training towards a decisive turn to the development of creative abilities of future specialists, as the learning process by merging with the scientific researches of students is increasingly becoming a real professional activity, which now forms the fundamentals of the development process of a future specialist" (Timofeeva et al. 2007, 462-463). The paper Lohonova (2010) and Chudesova (2008) states that "a scientific activity provides comparison of data, juxtaposition of judgments and opinions of different authors, elaboration of own views related to the issue, which is of the student's interest. The SRS system will enable the universities to train individuals with creative thinking, capable of having unconventional innovative thinking, which are so necessary for successful development of science and industry". The article describes various forms of research activities of students, including paying much attention to the project method of SRS implementation. "A project for a student means an opportunity to fully disclosure his/her creative potential, as well as it is the means of self-realization. It is an activity that allows a person to express himself/herself individually or in a group, to try one's hands at something, to apply own knowledge, to bring benefit, and to show the results achieved to the public" (Dubovina 2012, 124-126; Pokushalova 2011, 115-117).

This article summarizes the experience of the Chemistry Department of the Technological University of Tajikistan, as well as the applying types and forms of scientific researches of students.

\subsection{Research Work of Students: Types, Significance and Results}

An important and mandatory part of the educational process in the credit education system of the Technological University of Tajikistan is the individual work of students, planned by a teacher's guidance and without it. Allocation of as much credits 
as for class activities in the curriculum confirms the significance of students' individual work. It is well known a large number of forms of individual work, among which, in our opinion, scientific research occupy an important place.

While teaching chemical disciplines at the Chemistry Department of the Technological University of Tajikistan, the following types of student researches conducted successfully:

- Elaboration of papers and reviews on specific topics

- Research-intensive education (RIE)

- Involving students in implementing individual sections of researches on scientific subjects of the Department

- Execution of individual and group projects.

\subsection{Research-Intensive Education (RIE)}

The themes of research activities are to be approved at the Department meetings and to be as close as possible to the food production processes. The academic and research term papers, as a rule, deal with the study of physical and chemical characteristics of food, for example, determining the acidity of milk and dairy products by various methods, determining the qualitative composition of fruit and vegetable juice, and studying the laws of stability of disperse systems on the example of any article of food.

Performing of the semester research activity consists of a literature study, fulfilment of an experiment, designing a report and defending the paper outcomes. Such requirements for the term papers can solve the following problems:

- Reveal the creative potential of students.

- Develop the students' skills to work with literature.

- Develop the students' abilities to self-planning and implementing experiments.

- Foster better learning of the techniques for implementing laboratory experiments.

- Independently perform mathematical processing of the research results.

- Learn and apply the rules of drawing up and executing term papers and reports.

We believe that the semester papers in each chemical discipline, which executed in the form of educational and research activities with the students of the first and second courses, are the most important form of individual work with students. The results of these studies find practical application in the educational process. For example, laboratory work in physical chemistry "study of the polymers' properties" was preliminary tested by the students, as a research-intensive education semester. The laboratory practice in analytical chemistry also included a research-intensive education semester on "chromatographic separation of plant pigments". 
The students together with the teachers report the outcomes, both at the students and national conferences. Besides, the outcomes have been presented at the national competitions for the best students' papers and took the first and second places. But the main result of our work is to achieve the objectives mentioned in the beginning of this article.

\subsection{Involving Students in the Scientific Researches of the Department}

A form of individual work of students is to involve them in performing scientific researches of the Department, which enables students to develop their creative potential, to deepen the knowledge and to have insights of the essence, goals and objectives of the chosen specialty. Below the examples of application of similar studies in the educational process are provided. A second year student has conducted the study "The use of natural dyes in the production of dairy desserts". The aim of this study was to investigate the possibility of using dyes extracted from the flora of Tajikistan for colouring dairy products, which was one of the important topics of the Department of Chemistry. The study included familiarization with the literature on this subject and making a literature review, mastering the dairy desserts production technology under the laboratory conditions, studying the methods and conditions of dying the dairy products, and drawing up a report. While carrying out these types of activities, the student learned the theory about the requirements for the raw materials, as well as mastered various methods of milk analysing and standardizing (determination of acidity through acid-base and potentiometric titration, determination of milk fat by a butyrometer, defining the density by hydrometer), the technology of yoghurt production, as well as developed the methods for using and dosing of natural colouring extracts to obtain the optimal results. A part of the work performed, namely, the determination of the milk quality by different methods, was counted as the semester activity in analytical chemistry; the other part (determination of the properties of the resulting product) was counted as the semester activity in the physical and colloid chemistry. The results were presented at the scientific conference of students and aroused the interest of the audience, which is an incentive for further creative growth of students.

The following researches have been performed as part of the themes of the Department: "The study of the colour stability of the dye extracts by photocolorimetry method", "Determination of the dyes content in the natural food dyes", and "Determination of flavonoids and carotenoids in the food raw materials". 


\subsubsection{The Group Project}

In our view, the Department has an interesting experience on conducting of researches with the group of students enrolled in various courses. So, as per the students' scientific society program, the Department has been working on the study of the water quality of various rivers and sources in Tajikistan and its influence on the technological processes of food substances. Under this theme, there were identified hardness of water, content of oxygen, iron, manganese, and other elements in the water sources in the city of Dushanbe and the surrounding areas and the influence of the content of calcium, magnesium and iron on the quality of the canned products. The experiments on various aspects of this theme were performed by the students of the first, second and third year separately, and the analysis and synthesis of the results were made together.

\subsection{Outcomes}

The scientific and research efforts of the students in each chemical discipline has its own characteristics associated with both the specifics of a discipline and a contingent of students. The level of complexity of the research tasks depends on the course of studies of students. In the first year while studying inorganic chemistry, RIE aims at expanding and consolidating the knowledge and skills obtained in the lectures, laboratory works and seminars. As a rule, the first year students do not master the techniques of the laboratory practice. Therefore, they are asked to implement easy experimental and research activities, which develop their skills and abilities in making laboratory experiments. The examples of such work may be the following: "Water purification by distillation", "Salt cleaning by recrystallization and salting out-methods", "Determination of $\mathrm{pH}$ of the solutions by visual measurement", and "Solution preparation of the exact concentration".

On the second-third year, the themes of the students' researches relate to the analysis and determination of the physical and chemical properties of food products, i.e. analytical, physical, and colloid chemistry. Implementation of these activities requires more training of the students, and their abilities to have a creative approach to solving this problem. The above indicated could be confirmed by the example of "Determination of acidity of fruit and vegetable juice". The acidity determination is possible in several ways: by visual measurement, acid-base titration and potentiometric titration. The selection of the method depends on the characteristics of the object analysed, objectives of the study, and analysis of the conditions. For example, the acidity determination of the highly coloured juice is impossible by applying the methods of visual measurement and acid-base titration, 
as these methods are based on fixing indicators of colour changes depending on the acidity of the medium. The best method for these types of juice is to use potentiometric titration. At the same time, for the solutions (juice, beverage, etc.) that do not have an intense colour, the first two methods can be applied, but it requires multiple dilutions, which reduces the colour of the juice analysed but at the same time decreases the accuracy of determination. In the cases where no high accuracy of the results is required, and there is no possibility to use instrumental methods, the use of these methods is sufficiently justified. When performing RIE a student must take into account these nuances.

It should be noted that in addition to these analysis, the experimental part of the work includes preparation of a workplace, cleaning of the required chemical dishes, adjusting the devices and preparing solutions of the required concentration. After the experiment one needs to design a report on the work performed. Often, drawing up a report requires reflecting results of the experiment in the form of tables, graphs, and mathematical calculations. A report is to have a list of references.

The individual work of students while performing the above-indicated forms of the researches allows solving many problems such as:

- Mastering of theoretical material, which due to the limited time was not presented in the lectures

- Training on planning of experiments

- Consolidating the skills in implementing chemical experiments, which are acquired while performing laboratory and practical work (preparation of solutions, weighing, selection of indicators, work with devices, techniques for washing glassware, safety regulations, etc.)

- Learning on how to process mathematical and graphical results of experiments

- Gaining skills in working independently with literature and the Internet

- Learning the rules on making reports and term papers

- Identifying interrelations between disciplines on the example of using the knowledge of mathematics and engineering graphics in the course of mathematical and graphical processing of the results of the experiments

- Justifying for the necessity to study inorganic, organic, analytical, physical and colloid chemistry, and other disciplines for future professional activities.

\section{References}

Chudesova, G. P. (2008). Rol nauchno-issledovatelskoi raboty studentov v uchebnom processe. "Socialno-ekonomicheskoe polojenie Rossii v novyh geopoliticheskih I finansovoekonomicheskih usloviah: realii I perspektivy razvitia". Retrieved from http://www.ibl.ru/ konf/041208/89.html

Dubovina, O. S. (2012). Problemy i perspektivy razvitia obrazovania. Ispolzovanie proektnyh tehnologyi v formirovanii obshyh i professionalnyh kompetencyi obuchaushihsia., s. 124-126.

Lohonova, G. (2010). Lichnost, semia I obshestvo:voprosy pedagogiki I psihologii. Nauchnoissledovatelskaia rabota studentov VUZa kak komponent professionalnoi podgotovki budushih 
specialistov (sb. St. Po mater. 1 mejdunarodnoi nauchno-practicheskoi konferencii \#1 chast. Chast 2). Retrieved from https://sibac.info/conf/pedagog/i/35274

Pokushalova, L. V. (2011). Formirovanie umenyi I razvitie navykov samostoiatelnoi raboty studentov technicheskog o vuza. Molodoi uchenyi, 4, 115-117. Retrieved from http://moluch.ru/ archive/27/2899/

Timofeeva, E. M., Belik, N. P., \& Timofeeva, A. S. (2007). Fundamentalnye issledovania. Nauchno-issledovatskaia rabota studentov technicheskih vuzov (\#12-3). Retrieved from http:// cyberleninka.ru/article/n/nauchno-issledovatelskaya-rabota-studentov-tehnicheskih-vuzov

Open Access This chapter is licensed under the terms of the Creative Commons Attribution 4.0 International License (http://creativecommons.org/licenses/by/4.0/), which permits use, sharing, adaptation, distribution and reproduction in any medium or format, as long as you give appropriate credit to the original author(s) and the source, provide a link to the Creative Commons license and indicate if changes were made.

The images or other third party material in this chapter are included in the chapter's Creative Commons license, unless indicated otherwise in a credit line to the material. If material is not included in the book's Creative Commons license and your intended use is not permitted by statutory regulation or exceeds the permitted use, you will need to obtain permission directly from the copyright holder.

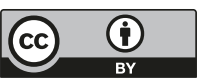

